\title{
SISTEM PERLINDUNGAN SUMBER DAYA BUDAYA TAK BENDA DI PALEMBANG, SUMATERA SELATAN, INDONESIA*
}

\author{
Miranda Risang Ayu ${ }^{* *}$, Rika Ratna Permata ${ }^{* * *}$ dan Laina Rafianti***** \\ Departemen Hukum Teknologi Informasi Komunikasi dan Kekayaan Intelektual \\ Fakultas Hukum, Universitas Padjadjaran \\ Jl. Dipati Ukur No. 35, Bandung, 40132
}

\begin{abstract}
This article analyses various potential Intangible Cultural Resources in Palembang and the possible legal protection system for them. Method used by this research was normative and legal-anthropological approach. Data were consisted of secondary data derived from written laws and primary data derived from the results of observation and semi-structured interviews. The results of the research showed that in Palembang there were 6 categories of Intangible Cultural Resources which could be protected by Intellectual Property legal regimes. It was also important to enhance an "integrative and inclusive" protection system in order to maximize the protection.
\end{abstract}

Keywords: intellectual property, culture, protection.

\section{Intisari}

Artikel ini membahas berbagai potensi Sumber Daya Budaya di Palembang serta sistem perlindungan hukum untuk memaksimalisasi perlindungan bagi potensi-potensi tersebut. Metode penelitian yang digunakan adalah yuridis normatif dan yuridis empiris khususnya yuridis antropologis. Data berasal dari data sekunder berwujud hukum tertulis maupun data primer hasil dari observasi lapangan dan wawancara semi terstruktur. Hasil penelitian menunjukkan bahwa di Palembang terdapat 6 kategori potensi Sumber Daya Budaya Tak Benda yang dapat dilindungi oleh sistem Hukum Kekayaan Intelektual. Sistem perlindungan yang integratif dan inklusif bagi potensi Sumber Daya Budaya di Palembang juga perlu dikembangkan untuk memaksimalisasi perlindungan.

Kata Kunci: kekayaan intelektual, budaya, perlindungan.

\section{Pokok Muatan}

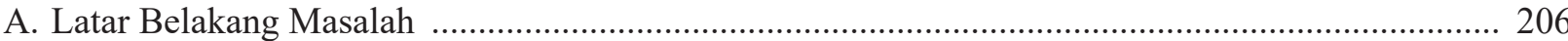

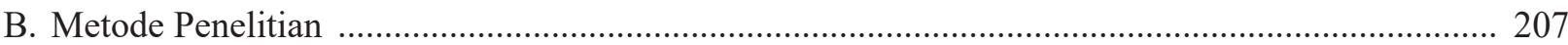

C. Hasil Penelitian dan Pembahasan ….................................................................................... 208

1. Kategori Sumber Daya Budaya Tak Benda yang Berpotensi untuk Mendapatkan Perlindungan Hukum Kekayaan Intelektual dan Ekspresi Budaya Tradisional 208

2. Sistem Perlindungan Integratif Kekayaan Intelektual Sumatera Selatan sebagai Model Suaka Sumber Daya Budaya Tak Benda di Tingkat Lokal Maupun Nasional Indonesia 214

D. Kesimpulan

Hasil Penelitian Strategis Nasional yang dibiayai oleh Direktorat Pendidikan Tinggi, Kementerian Pendidikan dan Kebudayaan Tahun 2014. Alamat korespondensi: miranda.risang.ayu@unpad.ac.id.

Alamat korespondensi: permata_rika@yahoo.com.

**** Alamat korespondensi: laina@unpad.ac.id. 


\section{A. Latar Belakang Masalah}

Sejauh ini, Indonesia termasuk lima besar negara-negara di dunia yang memiliki kekayaan etnik tradisional yang paling beragam. Kekayaan etnik ini mewujud dalam keberagaman Ekspresi Budaya Tradisional yang tinggi. Dari 8000 bahasa di dunia, hampir sepuluh persen bahasa di dunia ada di Indonesia. Motif batik, tarian, cerita rakyat, arsitektur tradisional, dan lagu daerah di Indonesia diperkirakan mencapai lebih dari 30.000 jenis. $^{1}$

Menurut Sensus Nasional Badan Pusat Statistik Tahun 2010, 10 provinsi di Indonesia dengan angka kemiskinan tertinggi adalah Papua Barat, Papua, Maluku, Sulawesi Barat, Nusa Tenggara Timur, Nusa Tenggara Barat, Aceh, Bangka-Belitung, Gorontalo, dan Sumatera Selatan. Meskipun demikian, kesepuluh provinsi itu memiliki potensi Sumber Daya Alam dan Budaya Tak Benda yang beragam. Salah satu provinsi yang menarik untuk diteliti adalah Sumatera Selatan. Terdapat dua faktor yang dipertimbangkan untuk memilih wilayah ini. Pertama, faktor adanya Komunitas Masyarakat Hukum Adat atau Kerajaan Lokal dan sebagai salah satu pasak historis di Indonesia dengan Kerajaan Sriwijayanya. ${ }^{2}$ Kedua, faktor adanya Sumber Daya Budaya Tak Benda yang potensial. Dengan kenyataan historis tersebut, Sumatera Selatan diasumsikan memiliki Pengetahuan Tradisional dan Ekspresi Budaya Tradisional yang berpotensi untuk ditingkatkan nilai ekonominya melalui perlindungan Kekayaan Intelektual (selanjutnya disingkat KI) dan Ekspresi Budaya Tradisional (selanjutnya disingkat EBT).

Persoalannya kemudian, sistem hukum yang berlaku positif di Indonesia belum mampu secara maksimal dan unifikatif memberikan perlindungan terhadap EBT Indonesia. Sejumlah ketentuan perlindungan masih merupakan ketentuan pengecualian yang tersebar di beberapa peraturan perundang-undangan. Ketentuan-ketentuan itu masih memerlukan penafsiran lanjut untuk kepastian hukum, dan sebagian besar tidak langsung mengatur EBT secara integratif. Sejauh ini, Indonesia baru memiliki Undang-Undang Nomor 11 Tahun 2010 tentang Cagar Budaya yang antara lain mengatur Sumber Daya Budaya yang bersifat material atau kebendaan dan Undang-Undang Nomor 28 Tahun 2014 tentang Hak Cipta (selanjutnya disebut UU Hak Cipta) yang salah satu pasalnya mengatur tentang EBT.

Perlindungan KI konvensional yang sekarang positif berlaku, merupakan sistem perlindungan bagi produk-produk industrial. Meski pun Hak Cipta tidak termasuk ke dalamnya, namun kepemilikannya yang mensyaratkan originalitas, keberadaan individu dan bukan kelompok masyarakat pencipta, serta bentuk yang termaterialisasi, berakar pada logika industrial juga. Internasionalisasi KI konvensional pun adalah logika dan sistem yang menjadi ciri khas kebangkitan peradaban Barat sejak Abad Pencerahan (Rennaisance/Aufklarung). Dalam Abad Pencerahan di Benua Eropa, dengan serentetan revolusi monumentalnya, secara jelas meletakkan kultur industrial sebagai sistem yang lebih maju dan modern dari sistem agraris yang tradisional. ${ }^{3}$

EBT merupakan aspek yang tak terpisahkan dalam pembentukan identitas suatu bangsa. Sayangnya, kepemilikan kolektif rakyat Indonesia terhadap Ekspresi Budaya Tradisionalnya tidak dapat diakomodasi dalam logika KI konvensional. Bagi KI konvensional, yang perlu dipersoalkan pemilikannya adalah karya kreatif yang sudah dimaterialisasi, bernilai baru, dimiliki individu,

Hokky Situngkir, "Kekayaan Budaya Indonesia", Makalah, Indonesian Archipelago Culture Initiatives (IACI) The National Workshop on Intellectual Property and the Documentation and Establishment of Database of Traditional Knowledge, Folklore and Intangible Cultural Heritage, UPT HKI UNPAD bekerja sama dengan Kementerian Luar Negeri, Kementerian Budaya dan Pariwisata, serta World Intellectual Property Organization (WIPO), 2011.

Pemerintah Provinsi Sumatera Selatan, "Sejarah Sumatera Selatan", http://www.sumselprov.go.id/index.php? module=content\&id=9, diakses 30 Mei 2013.

Miranda Risang Ayu, et al., 2013, Hukum Sumber Daya Genetik, Pengetahuan Tradisional, dan Ekspresi Budaya Tradisional di Indonesia, Alumni, Bandung, hlm. 5. 
dan menjadi bagian dalam proses komodifikasi dan industri. Semua rezim KI konvensional melihat produk-produk budaya tradisional, termasuk EBT, sebagai karya yang sudah tidak memiliki kebaruan, tidak diketahui lagi individu kreatornya, dan karenanya, harus dianggap sebagai sudah menjadi milik umum (public domain). Produk-produk yang sudah menjadi milik umum tidak mungkin lagi menikmati perlindungan $\mathrm{KI}$.

Berdasarkan hal-hal yang diuraikan pada latar belakang di atas, dapat dirumuskan masalahmasalah yang akan dibahas dalam tulisan ini sebagai berikut: Pertama, bagaimanakah kategorisasi sumber daya budaya tak benda yang berpotensi untuk mendapatkan perlindungan hukum KI dan Ekspresi Budaya Tradisional? Kedua, bagaimanakah sistem perlindungan integratif bagi potensi-potensi sumber daya budaya tak benda di tingkat lokal, khususnya di Sumatera Selatan, yang dapat menjadi model di tingkat nasional?

\section{B. Metode Penelitian}

Metode pendekatan yang digunakan dalam penelitian ini adalah metode yuridis normatif, yang menitikberatkan penelitian pada ketentuan hukum yang berlaku. Selain metode pendekatan yuridis normatif, penelitian ini juga menggunakan metode yuridis empiris, khususnya yuridis antropologis ${ }^{4}$ sehingga diharapkan tercipta hukum yang memperhatikan nilai budaya yang berlaku di masyarakat.

Sulistyowati mengatakan bahwa hukum sangatlah terkait dengan kebudayaan, dan karenanya, mengartikan hukum sebatas hukum undang-undang adalah tidak realistis, karena hukum adalah "dokumen antropologis yang hidup". 5 "Dokumen antropologis yang hidup" dapat diartikan secara luas, yakni sebagai dokumen yang memuat tata-nilai yang dijadikan panduan dalam melakukan interaksi keseharian kelompok masyarakat pengembannya, dan karenanya, dihidupkan oleh kelompok masyarakat pengemban tersebut dalam interaksi sosial mereka. Dokumen tersebut dapat juga ditulis dalam bahasa tradisional, dengan mempergunakan bahan-bahan dokumentasi yang biasa dipakai secara tradisional di dalam masyarakat tersebut, misalnya; kulit, serat kayu, logam atau daun lontar.

Spesifikasi penelitian ini adalah deskriptif analitis, yaitu dengan membandingkan berbagai instrumen Hukum Internasional dan Peraturan Perundang-undangan nasional Indonesia, kemudian melakukan analisis data yang didapat juga di lapangan, yang hasilnya dapat diterapkan untuk perlindungan Sumber Daya Budaya Tak Benda di Indonesia, khususnya di Sumatera Selatan.

Tahap penelitian ini meliputi: studi kepustakaan, studi lapangan ke Sumatera Selatan, dan analisis hasil-hasil penelitian. Teknik pengumpulan data yang digunakan adalah teknik studi dokumen yang dilakukan terhadap data sekunder untuk mendapatkan landasan teoretis, pendapat atau tulisan para ahli atau pihak lain berupa informasi, baik dalam bentuk tertulis maupun data elektronik. Teknik studi dokumen ini dilengkapi dengan teknik pengumpulan data primer di lapangan yang bersifat kualitatif, yang meliputi teknik pengamatan, teknik wawancara semi terstruktur dan teknik diskusi terfokus dengan responden-responden yang terkait erat dengan topik penelitian. Responden narasumber dalam penyusunan artikel ini antara lain: Farida, Dosen Sejarah, Universitas Sriwijaya; Syafarudin Adam dari LSM Cahaya Institut Palembang, dan Heri Wijaya Kepala Bidang Kebudayaan, Dinas Kebudayaan dan Pariwisata, Provinsi Sumatera Selatan. 


\section{Hasil Penelitian dan Pembahasan}

1. Kategori Sumber Daya Budaya Tak Benda yang Berpotensi untuk Mendapatkan Perlindungan Hukum Kekayaan Intelektual dan Ekspresi Budaya Tradisional

\section{a. Hak Cipta dan Hak Terkait}

Beberapa instrumen hukum internasional KI konvensional yang berkaitan dengan perlindungan Sumber Daya Genetik, Pengetahuan Tradisional dan Ekspresi Budaya Tradisional (SDG-PT-EBT), dapat dibedakan atas kelompok instrumen hukum internasional umum, dan instrumen hukum internasional yang terkait dengan sub-sub sistem atau rezim-rezim KI konvensional.

Instrumen hukum internasional yang melindungi sub-sub sistem KI konvensional dapat dibedakan menjadi tujuh rezim KI Konvensional yang termuat dalam Perjanjian TRIPS. ${ }^{6}$ Selain Perjanjian TRIPS, instrumen KI Konvensional yang dikhususkan untuk perlindungan Hak Cipta dan Hak Terkait diantaranya: Berne Convention for the Protection of Literary and Artistic Works 1886; Rome Convention 1961 concerning the International Convention for the Protection of Performers, Producers of Phonograms and Broadcasting Organizations; Geneva Convention 1971 for the Protection of Producers of Phonograms against Unauthorized Duplication of Their Phonograms, Brussels Convention 1974 relating to the Distribution of Programme Carrying Signals Transmitted by Satellite;WIPO Performances and Phonograms Treaty (WPPT) 1996; 7 WIPO
Copyright Treaty 1996; ${ }^{8}$ Beijing Treaty on the Protection of Audiovisual Performances 2012.

\section{b. Perlindungan Ekspresi Budaya Tradisional (EBT) dalam Hukum Nasional}

Hingga 2012, EBT di Indonesia dilindungi oleh beberapa ketentuan dalam peraturan perundang-undangan nasional yang tersebar. ${ }^{9}$ Peraturan perundang-undangan ini pun menyebut EBT dengan cara yang berbeda-beda, meski pun obyeknya berimpit. Dalam sistem hukum KI Konvensional, Ekpsresi Budaya Tradisional lebih dikenal dengan istilah "ciptaan yang tidak diketahui penciptanya" yang merujuk kepada folklor.

Folklor kemudian digantidengan istilah "Ekspresi Budaya Tradisional". Pemakaian istilah EBT ini dipengaruhi oleh pemakaian istilah "Traditional Cultural Expressions" dalam negosiasi internasional di forum World Intellectual Property Organization (WIPO). Kini, di tingkat nasional, istilah "Ekspresi Budaya Tradisional" pun telah menjadi istilah hukum, dengan pemakaiannya dalam UU Hak Cipta yang baru. Selain itu, istilah "Ekspresi Budaya Tradisional” juga dipakai secara dominan dalam Rancangan UndangUndang tentang Pengetahuan Tradisional dan Ekspresi Budaya Tradisional (RUU PT-EBT) Hak Inisiatif Dewan Perwakilan Daerah Republik Indonesia (DPD-RI) ${ }^{10}$ dan Rancangan Peraturan Pemerintah tentang EBT yang merupakan peraturan pelaksana dari ketentuan dalam UU Hak Cipta yang baru tersebut.

Berkaitan dengan upaya pengaturan

Agreement on Trade Related Aspects of Intellectual Property Rights, Annex Ic Agreement of Establishing of the World Trade Organization, 1994.

Keputusan Presiden Nomor 74 Tahun 2004 tentang pengesahan WIPO Performances and Phonograms Treaty (WPPT) 1996 (Lembaran Negara Republik Indonesia Tahun 2004 Nomor 93)

Keputusan Presiden Nomor 19 Tahun 1997 tentang Pengesahan WIPO Copyright Treaty 1996 (Lembaran Negara Republik Indonesia Tahun 1997 Nomor 36).

Miranda Risang Ayu, et al., Op. cit., hlm. 24

10 Hingga saat tulisan ini dibuat, masih berupa rancangan yang merupakan inisiasi Dewan Perwakilan Daerah, Kementerian Hukum dan Hak Asasi Manusia bersama beberapa kementerian terkait lainnya. 
EBT yang menjadi sumber daya ekonomi, muncul pula istilah "industri kreatif". Istilah "industri kreatif" ini mengemuka dengan ditetapkannya Instruksi Presiden Nomor 6 Tahun 2009 tentang Pengembangan Ekonomi Kreatif. Meski dari istilah tersebut, tampak jelas bahwa komodifikasi EBT hanya menjadi bagian atau bahan mentah dari keseluruhan industri kreatif yang beragam, namun, sesuai dengan sifat dari EBT yang terikat dan terkarakterisasi oleh tempat asal dan komunitas pemangkunya, perlindungan EBT atau Warisan Budaya Tak Benda sebagai Sumber Daya Budaya Tak Benda baru akan optimal jika melibatkan pengembangan lingkungan tempat asalnya. Tempat asal dari suatu EBT adalah tempat suatu EBT itu berakar, dijaga, dikembangkan, dan diturunkan dari generasi ke generasi, atau singkatnya, dihidupkan, oleh komunitas pemangkunya sendiri.

Seperti telah dikemukakan sebelumnya, pada perkembangannya, Undang-Undang Hak Cipta telah mengalami perubahan di tahun 2014. ${ }^{11}$ Perubahan tersebut yakni bahwa EBT diatur dalam Pasal 38 Bab V yang berjudul Ekspresi Budaya Tradisional dan Ciptaan yang dilindungi. Pasal 38 ayat (3) bab tersebut menyebutkan bahwa "Nilai-nilai yang hidup dalam masyarakat pengembannya adalah adat istiadat, norma hukum adat, norma kebiasaan, norma sosial, dan normanorma luhur lain yang dijunjung tinggi oleh masyarakat tempat asal, yang memelihara, mengembangkan, dan melestarikan ekspresi budaya tradisional." "12

Hingga saat ini di Sumatera Selatan masih terdapat nilai-nilai yang hidup dalam masyarakat pengembannya. ${ }^{13}$ Secara singkat, nilai-nilai yang hidup di Sumatera Selatan, khususnya Palembang dan sekitarnya, merupakan tatanan nilai yang dikarakterisasi oleh beberapa aspek penting, yakni:

a. Kenyataan historis pernah berdirinya pusat pengembangan religi Budha terbesar di Asia Tenggara yang kemudian mengalami transformasi dengan masuknya tradisi religi Islam ke bumi Nusantara;

b. Adanya kerajaan lokal yang kuat, baik yang berbasis tradisi religi Budha maupun Islam, yakni Kesultanan Palembang;

c. Adanya Sungai Musi dan anakanak sungainya, yang membuat kehidupan masyarakat Sumatera Selatan banyak diwarnai oleh kearifan lokal yang terilhami oleh keberadaan sungai besar tersebut, yang dapat juga disebut sebagai budaya air sungai atau tradisi air pedalaman, untuk membedakannya dari 'tradisi pesisiran' yang berkembang di sepanjang pesisir laut atau samudera. ${ }^{14}$

Pasal 38 ayat (1) UU Hak cipta menyebutkan bahwa Hak Cipta atas Ekspresi Budaya Tradisional dipegang oleh Negara.

11 Undang-Undang Nomor 28 Tahun 2014 tentang Hak Cipta (Lembaran Negara Republik Indonesia Tahun 2014 Nomor 266, Tambahan Lembaran Negara Republik Indonesia Nomor 5599).

12 Pasal 38 ayat (3) Undang-Undang Nomor 28 Tahun 2014 tentang Hak Cipta (Lembaran Negara Republik Indonesia Tahun 2014 Nomor 266, Tambahan Lembaran Negara Republik Indonesia Nomor 5599).

13 Wawancara dengan Farida, Dosen Sejarah, Universitas Sriwijaya, 3 Oktober 2014. Transkrip wawancara Recording 001-3 Oktober 2014 hlm. 4: "[...] pada umumnya (budaya) itu masih hidup tetapi terjadi degradasi itu ya penurunan nilai-nilai kepada generasi muda ambil contoh misalnya gini: kalangan menengah ya..ke atas ya, ini pengamatan aja ya pernah dipresentasikan itu di pra kongres di Pontianak ..orang menengah disini itu berbahasa dengan anaknya dengan menggunakan bahasa indonesia, benar kan? Gak tau mungkin merasa lebih keren atau apa gitu ya, seperti itu ..nanti di ibukota-ibukota kabupaten, kecamatan bahasa pengantar masyarakatnya itu belanja atau apa mereka menggunakan bahasa Palembang walaupun mereka masih menggunakan bahasa asli mereka, jadi benar generasi muda kayaknya lebih ke situ ..kalau adat perkawinan itu terjadi perubahan misalnya gini yang tadinya butuh berapa hari menjadi lebih singkat karena faktor biaya segala macem $[\ldots] "$. 
Pada ayat (2) disebutkan bahwa Negara wajib menginventarisasi, menjaga, dan memelihara ekspresi budaya tradisional. ${ }^{15}$ Sedangkan pada ayat (3) mengatur bahwa penggunaan EBT harus memperhatikan nilai-nilai yang hidup dalam masyarakat pengembannya. ${ }^{16}$ Meskipun telah dibentuk UU Hak Cipta yang baru Tahun 2014 tersebut, pengaturan tentang EBT masih belum jelas karena Pasal 38 ayat (4) mengamanatkan bahwa ketentuan lebih lanjut mengenai Hak Cipta yang dipegang Negara atas Ekspresi Budaya Tradisional diatur dengan Peraturan Pemerintah. ${ }^{17}$ Sementara itu atas inisiatif Dewan Perwakilan Daerah, bersama-sama dengan Tim Ahli Rancangan Undang-Undang, tengah diproses pembentukan Rancangan Undang-Undang tentang Pengetahuan Tradisional dan Ekspresi Budaya Tradisional.

Beberapa obyek EBT yang berwujud juga dilindungi dalam Pasal 40 UU Hak Cipta, yang memuat detail berbagai jenis Ciptaan yang dilindungi secara enumeratif. Obyek-obyek tersebut adalah segala bentuk pengetahuan, seni dan sastra, yang juga mencakup seni pertunjukan pewayangan, seni batik, beserta karya-karya dari hasil pengalihwujudannya. Hal yang menarik, terdapat perbedaan signifikan dari UndangUndang Hak Cipta sebelumnya. Pasal 40 ayat (1) UU Hak Cipta ini mengatur mengenai ciptaan yang dilindungi yang juga mencakup aspek dari EBT:

\section{$[\ldots]$}

o. terjemahan, adaptasi, aransemen, transformasi, atau modifikasi ekspresi budaya tradisi- onal;

q. kompilasi Ekspresi Budaya Tradisional selama kompilasi tersebut merupakan karya yang asli. ${ }^{18}$

Jangka waktu perlindungan karya cipta yang merupakan hasil modifikasi EBT dan kompilasi EBT, sebagaimana diatur dalam Pasal 59 Huruf j dan h Undang-Undang Hak Cipta adalah 50 tahun sejak pertama kali sejak dilakukan pengumuman. ${ }^{19}$ Adapun jangka waktu perlindungan EBT yang dipegang oleh Negara berlaku tanpa batas waktu.

\section{c. Perlindungan Indikasi Geografis dan Indikasi Asal}

Indikasi Geografis dan Indikasi Asal adalah rezim dan sub-rezim perlindungan dalam hukum KI konvensional yang pemegangnya bukan individu, melainkan asosiasi, kelompok atau komunitas. Selain klausul dalam UU Hak Cipta Nomor 28 Tahun 2014 yang mengatur EBT, rezim yang diatur dalam Undang-Undang Nomor 20 Tahun 2016 tentang Merek dan Indikasi Geografis ini dapat dipakai untuk melengkapi upaya perlindungan bagi Sumber Daya Budaya Tak Benda, khususnya berbagai jenis EBT maupun ekspresi-ekspresi seni yang memakai EBT sebagai bahan baku utamanya.

Pasal 1 angka 6 Undang-Undang Merek dan Indikasi Geografis Nomor 20 Tahun 2016 mendefiniskan Indikasi Geografis sebagai:

[...] suatu tanda yang menunjukkan daerah asal suatu barang dan/atau produk, yang karena faktor lingkungan geografis termasuk faktor alam, faktor manusia atau kombinasi dari kedua faktor tersebut, memberi reputasi

\footnotetext{
Pasal 38 ayat (1) Undang-Undang Nomor 28 Tahun 2014 tentang Hak Cipta (Lembaran Negara Republik Indonesia Tahun 2014 Nomor 266 , Tambahan Lembaran Negara Republik Indonesia Nomor 5599).

16 Pasal 38 ayat (3) Undang-Undang Nomor 28 Tahun 2014 tentang Hak Cipta (Lembaran Negara Republik Indonesia Tahun 2014 Nomor 266 , Tambahan Lembaran Negara Republik Indonesia Nomor 5599).

17 Pasal 38 ayat (4) Undang-Undang Nomor 28 Tahun 2014 tentang Hak Cipta (Lembaran Negara Republik Indonesia Tahun 2014 Nomor 266, Tambahan Lembaran Negara Republik Indonesia Nomor 5599).

18 Pasal 40 ayat (1) Undang-Undang Nomor 28 Tahun 2014 tentang Hak Cipta (Lembaran Negara Republik Indonesia Tahun 2014 Nomor 266, Tambahan Lembaran Negara Republik Indonesia Nomor 5599).

19 Pasal 59 huruf j dan h Undang-Undang Nomor 28 Tahun 2014 tentang Hak Cipta (Lembaran Negara Republik Indonesia Tahun 2014 Nomor
} 266, Tambahan Lembaran Negara Republik Indonesia Nomor 5599). 
kualitas dan karakteristik tertentu pada barang dan/atau produk yang dihasilkan. ${ }^{20}$

Indikasi Asal atau Indikasi Sumber, menurut Pasal 63 Undang-Undang Merek dan Indikasi Geografis Nomor 20 Tahun 2016 dilindungi, meskipun tanpa melalui kewajiban pendaftaran sebagai tanda yang menunjukkan asal suatu barang dan/atau jasa yang benar dan dipakai dalam perdagangan. ${ }^{21}$ "Nama Dagang" atau "Trade Name" yang diatur dalam Article 8 Konvensi Paris tentang Perlindungan Kekayaan Industrial, sepanjang merupakan Nama Dagang yang dipegang oleh sekelompok orang atau asosiasi, dapat disamakan dengan Indikasi Asal menurut Undang-Undang Merek dan Indikasi Geografis tersebut. ${ }^{22}$

\section{d. Pelestarian Warisan Budaya Tak Benda \\ UNESCO sebagai salah satu organ} PBB yang khusus bergerak di bidang pendidikan, sosial dan kebudayaan, telah meletakkan sejumlah hukum internasional, baik yang mengikat maupun tidak mengikat, dalam rangka pelestarian Warisan Budaya. Ruang lingkup hukum internasional UNESCO ini mencakup obyek-obyek yang bersifat material (benda) maupun imaterial (tak benda). Sebaliknya, instrumen UNESCO justru meyakini bahwa komodifikasi produkproduk budaya tidak boleh melemahkan nilai-nilai luhurnya untuk kepentingan pengembangan seluruh umat manusia. Menurut instrumen internasional UNESCO, kepentingan pengembangan seluruh umat manusia harus diletakkan melebihi kepen- tingan untuk sekedar pemenuhan kebutuhan fisikal material saja.

Dewasa ini, konvensi yang banyak dipakai dan dianggap sebagai sumber air segar untuk melindungi keberadaan sejumlah EBT adalah Konvensi UNESCO tentang Pelestarian Warisan Budaya Tak Benda 2003 atau lazim disebut sebagai Konvensi UNESCO 2003. Konvensi ini telah diratifikasi oleh Indonesia melalui Peraturan Presiden Nomor 78 Tahun 2007.23 Indonesia telah secara aktif mendaftarkan beberapa obyek kekayaan budayanya berdasarkan sistem Konvensi UNESCO 2003 ini, contohnya Batik dan Angklung.

Konvensi UNESCO 2003 karena memiliki sifat perlindungannya yang non ekonomis, memakai istilah "safeguarding" dan bukan "protecting". Makna perlindungan ini lebih dekat pada aspek penjagaan yang bersifat inklusif, dan bukan perlindungan yang bersifat eksklusif atau meniadakan hak pihak lain yang bukan pemegangnya untuk bebas menikmatinya. "Safeguarding", lebih bersifat menjaga objek yang dilindungi agar tetap lestari bagi kepentingan generasi umat manusia, di masa sekarang maupun masa yang akan datang. Dalam sistem KI konvensional, perlindungan Konvensi UNESCO 2003 ini tetap mengakui bahwa semua obyek yang dilindunginya telah berada dalam ranah publik (public domain).

Konvensi UNESCO 2003 juga menetapkan obyek-obyek yang harus dijagai. Pasal 2 Ayat (1) Konvensi UNESCO 2003 menyebutkan bahwa "Warisan budaya tak benda meliputi berbagai praktik, representasi,

20 Pasal 1 angka 6 Undang-Undang Nomor 20 Tahun 2016 tentang Merek dan Indikasi Geografis (Lembaran Negara Republik Indonesia Tahun 2016 Nomor 252, Tambahan Lembaran Negara Republik Indonesia Nomor 5953).

21 Pasal 63 Undang-Undang Nomor 20 Tahun 2016 tentang Merek dan Indikasi Geografis (Lembaran Negara Republik Indonesia Tahun 2016 Nomor 252, Tambahan Lembaran Negara Republik Indonesia Nomor 5953).

22 Selanjutnya, kategorisasi bentuk-bentuk sumber daya budaya yang merupakan indikasi geografis dan indikasi asal dijelaskan pada sub bab berikutnya mengenai sistem perlindungan integratif sumber daya budaya tak benda di tingkat lokal maupun nasional.

23 Peraturan Presiden Nomor 78 Tahun 2007 tentang pengesahan Konvensi UNESCO tentang Pelestarian Warisan Budaya Takbenda 2003 (Lembaran Negara Republik Indonesia Tahun 2007 Nomor 81). 
ekspresi, pengetahuan, keterampilan - serta instrumen, obyek, artefak, dan ruang-ruang budaya terkait - tempat komunitas, kelompok, dan dalam kasus-kasus tertentu, individu, mendakunya sebagai bagian dari warisan budaya mereka." ${ }^{24}$ Dari ketentuan ini, dapat disimpulkan bahwa jenis-jenis warisan budaya tak benda meliputi segala jenis praktik, representasi, ekspresi, pengetahuan, keterampilan - juga peralatan, objek, artefak, dan ruang kultural terkait - yang diakui oleh komunitas, kelompok, dan dalam beberapa kasus, individu, sebagai bagian dari warisan budaya mereka.

Konvensi UNESCO 2003 dibuat dalam rangka menegaskan inklusivitas hakhak yang diaturnya, juga menyebutkan tujuan dari penjagaan warisan budaya takbenda dalam Pasal 19 ayat (2) Konvensi UNESCO 2003 mengenai kerjasama. Secara singkat, tujuan akhir yang dapat disimpulkan dari Pasal 19 ayat (2) Konvensi UNESCO 2003 adalah untuk kepentingan kemanusiaan secara umum. Jadi, kebebasan versi Konvensi UNESCO 2003 bukan untuk kepentingan industrial, tetapi sebaliknya, untuk kepentingan pemanusiaan personapersona seluruh umat manusia.

\section{e. Sumber Daya Budaya Tak Benda di Sumatera Selatan}

Provinsi Sumatera Selatan secara administratif terdiri dari 13 (tiga belas) Pemerintah Kabupaten dan 4 (empat) Pemerintah Kota, beserta perangkat Dewan Perwakilan Rakyat Daerah. Pemerintah
Kabupaten dan Kota membawahi Pemerintah Kecamatan dan Desa/ Kelurahan. ${ }^{25}$ Setiap kota memiliki 3 (tiga) bahasa ${ }^{26}$ sehingga terlihat bahwa Palembang sebagai ibu kota provinsi sangat kaya akan budaya. Mata pencaharian utama masyarakatnya berkembang melalui sektor perdagangan, terutama lada dan rempah-rempah. Selain itu, terdapat juga perdagangan yang berbasis industri rumah tangga yaitu makanan olahan ikan dan kain tenun. Terkait hal ini, Farida $^{27}$ mengungkapkan, bahwa apabila menggunakan teori dari Heddy Shri Ahimsa Putra, ${ }^{28}$ pemetaan nilai budaya lebih mudah melalui bahasa. Selain keragaman bahasa, di Sumatera Selatan juga ditemukan beberapa situs yang sangat banyak dan beragam dan tersebar di berbagai wilayah Kabupaten, terutama di Kabupaten Lahat dan Ogan Komering Ulu.

Sejarah kepurbakalan Sumatera Selatan dibagi secara periodik. Setiap periode memperlihatkan keunikan yang beragam, yang berkaitan dengan unsur penting dalam kehidupan manusia. Dalam konteks Sumber Daya Budaya Tak Benda, telah ditemukan sejumlah teknologi tradisional yang berkembang pada masa Plestosen. Teknologi tradisional tersebut juga ditemukan di daerah Situs Baturadja, yaitu di sepanjang Daerah Aliran Sungai Ogan dan Sungai Lengkayap, Kabupaten Ogan Komering Ulu, Provinsi Sumatera Selatan. ${ }^{29}$ Selain peninggalan arkeologis tersebut, wilayah Sumatera Selatan mempunyai

Pasal 2 ayat (1) Konvensi UNESCO tentang Pelestarian Warisan Budaya Takbenda 2003.

Pemerintah Provinsi Sumatera Selatan, "Sekilas Sumatera Selatan”, http://www.sumselprov.go.id/profil/sekilas, dikases tanggal 12 September 2014. Pemerintahan Kabupaten/Kota di Sumatera Selatan: Kab. Ogan Komering Ulu (Ibukota Baturaja); Kab. OKU Timur (Ibukota Martapura); Kab. OKU Selatan (Ibukota Muara Dua); Kab. Ogan Komering Ilir (Ibukota Kayu Agung); Kab. Muara Enim (Ibukota Muara Enim); Kab. Lahat (Ibukota Lahat); Kab. Musi Rawas (Ibukota Lubuk Linggau); Kab. Musi Banyuasin (Ibukota Sekayu); Kab. Banyuasin (Ibukota Pangkalan Balai); Kab. Ogan Ilir (Ibukota Indralaya); Kab. Empat Lawang (Ibukota Tebing Tinggi); Kota Palembang (Ibukota Palembang); Kota Pagar Alam (Ibukota Pagar Alam); Kota Lubuk Linggau (Ibukota Lubuk Linggau); Kota Prabumulih (Ibukota Prabumulih); Kab. Penukal Abab Lematang Ilir (Ibukota Talang Ubi); Kab. Musi Rawas Utara (Ibukota Rupit).

26 Wawancara dengan Heri Wijaya Kepala Bidang Kebudayaan, Dinas Kebudayaan dan Pariwisata, Provinsi Sumatera Selatan, 2 Oktober 2014.

Wawancara dengan Farida, dosen Universitas Sriwijaya, 3 Oktober 2014.

28 Lihat Heddy Shri Ahimsa Putra, 2006, Strukturalisme Levi-Strauss: Mitos dan Karya Sastra, Kepel Press, Yogyakarta, hlm. 25. 
Sumber Daya Alam berupa pegunungan kapur, yaitu Bukit Barisan.

Kegiatan ekonomi masyarakat lebih berfokus di bidang pertanian dan perkebunan, utamanya tanaman padi sawah, tanaman kopi dan sayur-sayuran. Khusus di wilayah Sumatera Selatan, warga masyarakat melakukan penyelamatan dan pemeliharaan lingkungan secara sinambung dengan cara menjaga agar berperilaku mereka selalu memperhatikan etika, tabu dan ketentuan adat yang harus dipatuhi. Semua ini berakar dari nilai-nilai yang tumbuh dalam masyarakat selama ratusan tahun, selalu dijadikan pedoman dalam berperilaku, dan dituangkan dalam petata petiti..$^{30}$

Kearifan lokal ini dipelihara oleh masyarakat pengemban di Palembang melalui tradisi lisan. Caranya adalah dengan diucapkan oleh anggota masyarakat dalam peristiwa-peristiwa penting maupun kehidupan sehari-hari, dengan membuat nilai-nilai budaya yang berkaitan dengan kepentingan alam. Masyarakatnya Palembang, dalam keseharian mereka, memperhatikan petatapetiti dengan harapan mereka agar mereka mendapat berkah dan terhindar dari musibah. Manfaat kepatuhan terhadap petata-petiti ini dipandang sebagai salah satu kearifan lokal dari masyarakat Palembang. ${ }^{31}$

Sumatera Selatan memiliki budaya air yang khas, yakni budaya air sungai. Sumatera Selatan, khususnya Palembang, bahkan dapat disebut sebagai wialayah di Indonesia dengan budaya air sungai terkuat, karena wilayah ini dialiri oleh ratusan sungai menganak sungai, yang hingga kini dikenal dengan istilah
Batang Hari Sembilan.

Budaya air sungai yang kuat di Sumatera Selatan tampak dari berbagai ekspresi budaya material yang dihasilkan oleh Kesultanan Palembang. Beberapa ekspresi budaya material Kesultanan Palembang yang penting adalah situs-situ bangunan yang berhubungan dengan air, seperti situs pengairan, situs bendungan, dan situs pelabuhan. Situs-situs arsitektur dan teknologi tradisional yang berhubungan dengan air ini mendominasi warisan budaya material Kesultanan Palembang, bukan situs istana atau tempat pemujaan seperti di Jawa atau Bali.

Konteks ekpresi budaya tradisional tak benda atau imaterial, budaya air sungai ini nyata mempengaruhi ragam gerak taritarian yang berkembang dari Kesultanan Palembang, baik ketika Palembang masih menjadi pusat pengembangan Budha terbesar di Asia Tenggara, maupun ketika Palembang sudah menjadi Kesultanan Darussalam yang bernuansa Islam. Perpindahan ragam gerak tari-tarian Palembang, terutama yang ditarikan oleh perempuan, amat feminine dan sepenuhnya mengalir seperti gelombang dan riak-riak air sungai. Tidak ada jeda atau hentakan yang menjadi aksentuasi dominan.

Salah satu adat-istiadat Kesultanan Palembang Darussalam yang perlu dilestarikan adalah upacara perkawinan tujuh hari tujuh malam dengan adat berangkat tujuh turunan. Pelaksanaan upacaranya dilakukan selama tujuh hari tujuh malam dengan melibatkan berbagai kalangan masyarakat, mulai dari kaum perempuan, laki-laki,

29 Dinas Kebudayaan dan Pariwisata Provinsi Sumatera Selatan, 2006, Profil Peninggalan Sejarah dan Purbakala Sumatera Selatan, Dinas Kebudayaan dan Pariwisata Provinsi Sumatera Selatan, Palembang, hlm vii.

30 Erlina, "Kearifan Lingkungan pada Masyarakat Basemah, Lahat, Sumatera Selatan", dalam Purba, Jonny, 2003, Bunga Rampai Kearifan Lingkungan, Kementerian Lingkungan Hidup, Jakarta, hlm. 79. Contoh petata petiti: masyarakat yang mandi di sungai harus memperhatikan nilai-nilai yang hidup yaitu dilarang mandi di hulu, juga diharuskan berpakaian dalam mencuci, sehingga sungai akan terjaga kebersihannya; dilarang memotong dahan atau ranting tempat bertengger burung; apabila menemukan uang maka harus dikembalikan.

31 Erlina, Loc.cit. Bandingkan dengan Undang-undang Simbur Cahaya, yaitu hukum adat yang dibuat oleh Ratu Sinuhun, yaitu permaisuri Sultan Palembang pada abad ke-16. 
remaja, bujang atau gadis, orang-orang tua, sampai anak-anak. Rangkaian adat upacara perkawinan tersebut terdiri atas: $:^{32}$ persiapan sebelum perkawinan, perkawinan, dan setelah perkawinan.

Instrumen hukum KI yang digunakan untuk menganalisis kategorisasi Sumber Daya Budaya Tak Benda yang berpotensi uuntuk mendapatkan perlindungan hukum KI yang terdekat adalah UU Hak Cipta, meskipun Undang-Undang ini tidak secara komprehensif mengatur Sumber Daya Budaya Tak Benda. Pasal 38 ayat (1) UU Hak Cipta mengamanatkan pada Negara untuk memegang Hak Cipta atas EBT. ${ }^{33}$ Pengertian EBT berdasarkan penjelasan Undang-Undang ini adalah mencakup salah satu atau kombinasi bentuk ekspresi sebagai berikut: verbal tekstual, baik lisan maupun tulisan,yang berbentuk prosa maupun puisi, dalam berbagai tema dan kandungan isi pesan, yang dapat berupa karya sastra ataupun narasi informatif; musik, mencakup antara lain, vokal, instrumental, atau kombinasinya; gerak, mencakup antara lain, tarian; teater, mencakup antara lain, pertunjukan wayang dan sandiwara rakyat; seni rupa, baik dalam bentuk dua dimensi maupun tiga dimensi yang terbuat dari berbagai macam bahan seperti kulit, kayu, bambu, logam, batu, keramik, kertas, tekstil, dan lain-lain atau kombinasinya; dan upacara adat. ${ }^{34}$ Oleh karena itu, berdasarkan penelitian yang dilakukan, sumber daya budaya tak benda lebih luas daripada kategorisasi yang dimuat dalam Undang-Undang Hak Cipta. Sumber daya budaya tak benda meliputi juga sumber daya genetik dan pengetahuan tradisional.

\section{Sistem Perlindungan Integratif Kekayaan Intelektual Sumatera Selatan sebagai Model Suaka Sumber Daya Budaya Tak Benda di Tingkat Lokal Maupun Nasional Indonesia}

Peta administratif tidak selalu dapat diterapkan sebagai peta budaya. Sebenarnya, wilayah suaka sumber daya budaya tak benda kurang cocok apabila diterapkan pada provinsi/kota/kabupaten tertentu. Selama ini, di Sumatera Selatan, khususnya di Palembang, bukan tidak ada upaya-upaya pelestarian yang dilakukan oleh Pemerintah dan pemerintah daerah. Contoh sederhana, untuk pelestarian seni rupa dilakukan pameran lukisan, demo melukis hingga lomba melukis. ${ }^{35}$ Adanya pendidikan formal untuk seni rupa juga merupakan salah satu upaya revitalisasi sumber daya budaya tak benda, meskipun tidak langsung. Akan tetapi, kegiatan-kegiatan seperti ini cenderung bersifat komodifikasi dengan tidak cukup menitikberatkan upaya untuk mempertahankan nilai-nilai budaya itu sendiri. Kegelisahan yang mengemuka kemudian adalah kekhawatiran diambilnya budaya Indonesia di kawasan Sumatera Selatan oleh negara lain, khususnya oleh negara serumpun, seperti Malaysia. Hal ini merupakan salah satu sebab revitalisasi budaya marak dilakukan.

Konteks global, potensi-potensi sistem perlindungan yang tepat untuk sumber daya budaya tak benda tengah dibahas oleh Organisasi Kekayaan Intelektual Dunia (The World Intellectual Porperty Organization/WIPO) dalam Intergovernmetal Committee on Intellectual Property and Genetic Resources, Traditional Knowledge and Traditional Cultural Expressions. Definisi EBT yang mengemuka dalam forum ini adalah sebagai berikut:

Traditional cultural expression means any

32 Amran Halim, 2014, Direktori Kesenian Sumatera Selatan, Dinas Kebudayaan dan Pariwisata Provinsi Sumatera Selatan, Palembang, hlm. 118.

33 Pasal 38 ayat (1) Undang-Undang Nomor 20 Tahun 2016 tentang Merek dan Indikasi Geografis (Lembaran Negara Republik Indonesia Tahun 2016 Nomor 252, Tambahan Lembaran Negara Republik Indonesia Nomor 5953).

34 Bagian Penjelasan Undang-Undang Nomor 20 Tahun 2016 tentang Merek dan Indikasi Geografis (Lembaran Negara Republik Indonesia Tahun 2016 Nomor 252, Tambahan Lembaran Negara Republik Indonesia Nomor 5953).

35 Ibid. 
form of artistic and literary, creative and other spiritual] expression, tangible or intangible, or a combination thereof, such as actions ${ }^{36}$, materials $^{37}$, music and sound ${ }^{38}$, verbal and written and their adaptations ${ }^{39}$, regardless of the form in which it is embodied, expressed or illustrated which may subsist in written/ codified, oral or other forms. ${ }^{40}$

Beberapa potensi dari Sumatera Selatan sebagaimana telah dijelaskan sebelumnya telah memenuhi kriteria definisi WIPO ini. Ruang lingkup perlindungan EBT dari Sumatera Selatan juga mendekati ruang lingkup yang diusulkan oleh WIPO, yaitu dihasilkan dan dikembangkan secara komunal, oleh sekelompok masyarakat tertentu, merupakan produk yang unik dan berhubungan dengan identitas sosial komunitas tertentu, dan disampaikan dari generasi ke generasi.

Pola lain untuk membentuk model suaka sumber daya budaya tak benda juga ditawarkan oleh Konvensi UNESCO 2003 tentang Pelestarian Warisan Budaya Takbenda (the Safeguarding of Intangible Cultural Heritage of Mankind). Meski pun demikian, terdapat perbedaan karakter antara instrumen hukum internasional yang diusung oleh forum WIPO dan UNESCO. Konvensi UNESCO 2003 menitikberatkan pada pelestarian, bukan pada perlindungan hukum terhadap hak ekonomi sumber daya seperti umumnya konvensi-konvensi yang dibidani WIPO dalam bidang KI.

Pentingnya "ketersediaan yang berkesinambungan" dalam Konvensi UNESCO 2003 mengandung makna yang dalam, yang meletakkan komersialisasi dan komodifikasi dalam ranah 'precautionary'atau ranah perlunya diberlakukan prinsip kehati-hatian. Hal ini dikarenakan kecenderungan eksploitatif jangka pendek dari komersialisasi dan komodifikasi justru dapat mengancam keberadaan nilai spiritual dan keutuhan obyek-obyek yang sinambung. Dalam konteks ini, menjadi logis jika hak-hak yang diatur dalam Konvensi UNESCO 2003 ini adalah hak-hak yang sepenuhnya inklusif atau meluas-terbuka, bagi seluruh umat manusia. Hak-hak ini justru meneguhkan kenyataan bahwa obyek-obyek yang dijaga harus tetap ada dalam ranah kepemilikan bersama atau public domain. Lebih tegasnya, ketentuan-ketentuan UNESCO Convention 2003 adalah ketentuan-ketentuan yang meletakkan dasar aturan main di dalam ranah kepemilikan bersama tersebut, dan bukannya membatasi, membagi dan mengaksentuasi ranah kepemilikan bersama dengan meletakkan hak-hak eksklusif.

Konteks Indonesia, dalam hukum nasionalnya telah memiliki pendekatan khusus untuk pemanfaatan budaya tak benda sebagai basis pengembangan kreativitas. Namun demikian, hal ini masih belum bersifat integratif. Dengan asumsi bahwa Sumber daya budaya tak benda meliputi EBT, Pasal 38 Undang-Undang Hak Cipta Nomor 28 Tahun 2014 telah mengatur perlindungannya secara khusus, yakni sebagai Hak Cipta berbasis komunitas atau Hak Cipta komunitas, yang penjagaan dan pemeliharaannya dipegang oleh Negara.

Kedudukan Negara dalam Pasal 38 UU Hak Cipta ini mengisyaratkan kewajiban Negara dalam menginventarisasi, menjaga dan memelihara suatu EBT untuk kepentingan utama pemilik Hak Cipta komunal yang original, yakni masyarakat pengemban. Kewajiban untuk melakukan

36 Dalam forum tersebut dikemukakan sebagai bagian dari actions adalah dance, works of mas, plays, ceremonies, rituals, rituals in sacred places and peregrinations, games and traditional sports/sports and traditional games, puppet performances, and other performances, whether fixed or unfixed.

37 Dalam forum tersebut dikemukakan sebagai bagian dari materials adalah expressions of art, handicrafts, ceremonial masks or dress, handmade carpets, architecture, and tangible spiritual forms, and sacred places.

38 Dalam forum tersebut dikemukakan sebagai bagian dari music and sound adalah songs, rhythms, and instrumental music, the songs which are the expression of rituals.

39 Dalam forum tersebut dikemukakan sebagai bagian dari verbal and written [and their adaptations] adalah stories, epics, legends, popular stories, poetry, riddles and other narratives; words, signs, names and symbols.

40 Organisasi Kekayaan Intelektual Dunia (The World Intellectual Porperty Organization/WIPO) dalam Intergovernmetal Committee on Intellectual Property and Genetic Resources, Traditional Knowledge and Traditional Cultural Expressions. 
inventarisasi EBT harus diartikan sebagai kewajiban Negara untuk melakukan upaya perlindungan defensif EBT melalui pembuatan basis data, sehingga komodifikasi EBT tidak mencerabut kemanfaatan ekonominya bagi masyarakat pengemban.

Pemanfaatan suatu EBT pun harus memperhatikan nilai-nilai yang hidup, dan dilakukan dengan cara yang tidak menyudutkan atau bahkan melemahkan kedudukan masyarakat pengemban. Dari perspektif Hak Asasi Budaya atau Hak Kebudayaan, hak dari masyarakat pengemban terhadap EBT mereka merupakan Hak Asasi Budaya yang bersifat positif, yang mewajibkan Negara untuk berperan aktif dalam pemenuhan, perlindungan dan pengimplementasiannya.

Seperti telah diuraikan di bagian awal tulisan ini, rezim hukum KI konvensional yang paling menjanjikan untuk memperkuat perlindungan Sumber Daya Budaya, khususnya yang berbasis EBT dan/atau Warisan Budaya Tak Benda adalah Indikasi Geografis dan Indikasi Asal atau Indikasi Sumber berdasarkan Undang-Undang Nomor 20 Tahun 2016 tentang Merek dan Indikasi Geografis. Hal ini disebabkan oleh karakter kepemilikan Indikasi Geografis dan Indikasi Asal yang sepenuhnya bersifat komunal.

Secara spesifik, Indikasi Geografis dan Indikasi Asal dapat digunakan untuk menjamin agar produk yang telah siap dipasarkan akan menikmati perlindungan eksklusif dari produk-produk sejenis saingannya, yang tidak dihasilkan dari tempat asal produk tersebut, namun ikut mendompleng reputasi tempat produk dengan mencantumkan nama asal yang salah atau menyesatkan konsumen. Dengan Indikasi Geografis, produk akan mendapatkan kepercayaan konsumen yang jauh lebih tinggi dari pada sebelum produk itu dilindungi, karena Indikasi Geografis juga memberi jaminan kualitas prima dan kontrol atas produk yang berasal dari keunikan tempat asal produk tersebut.

Produk-produk potensial dari Sumatera Selatan pada dasarnya dapat menikmati perlindungan Indikasi Asal atau Indikasi Sumber. Selain itu, beberapa produk seperti Ukiran, Songket dan Jumputan Palembang, atau replika dari beberapa situs prasejarah dan peninggalan masa Hindu dan Budha di daerah Sumatera Selatan, dapat juga diberdayakan agar dapat menikmati perlindungan eksklusif Indikasi Geografis. Tabel di bawah ini menggambarkan kemungkinan perlindungan integratif berdasarkan Hukum KI yang kini positif berlaku di Indonesia di Palembang.

Berdasarkan pengamatan yang didapat di lapangan, Palembang adalah wilayah urban yang berasal dari salah satu kerajaan dan pusat peradaban paling berpengaruh di Asia Tenggara dan Asia Tengah, yakni Kerajaan Sriwijaya. Situs-situs budaya air sungai yang ditinggalkannya masih dapat ditemukan di sekitar ibukota Sumatera Selatan itu. Dalam konteks ini, diperlukan sistem penentuan kewilayahan yang berbeda dan kompleks dari kewilayahan Desa atau Desa Adat.

Tabel 1.

Perlindungan Hukum Kekayaan Intelektual Sumber Daya Budaya Palembang

\begin{tabular}{lcccccc}
\hline \multicolumn{7}{c}{ Ekspresi Verbal, Tekstual, Lisan, Tulisan } \\
\end{tabular}




\begin{tabular}{lccc}
\hline - Cerita Dayang Merindu & $\mathrm{X}$ & $\mathrm{X}$ & $\mathrm{X}$ \\
\hline - Syair: Sinyor Kista; Nuri; Patut & $\mathrm{X}$ & $\mathrm{X}$ & $\mathrm{X}$ \\
$\begin{array}{l}\text { Delapan; Kembang Air Mawar; Perang } \\
\text { Menteng; }\end{array}$ & & & \\
\hline - Wayang Palembang. & $\mathrm{X}$ & $\mathrm{X}$ & $\mathrm{X}$ \\
\hline - Syair Abdul Muluk; & & &
\end{tabular}

- Syair Abdul Muluk; $\quad$ X

- Rubrik: Wak Dolah; Rubrik Mang Juhai. $\quad$ X

\section{Ekspresi Musik}

\begin{tabular}{cccccc} 
Hak & Indikasi & Indikasi & Ekspresi \\
Cipta & Asal & Geografis & $\begin{array}{c}\text { Warisan } \\
\text { Bradisional }\end{array}$ & $\begin{array}{c}\text { Benda } \\
\text { Tadaya } \\
\text { Tak Benda }\end{array}$ & $\begin{array}{c}\text { Cagar } \\
\text { Budaya }\end{array}$ \\
\hline & & $\mathrm{X}$ & $\mathrm{X}$ & $\mathrm{X}$
\end{tabular}

- Gamelan Slendro dan Pelog

$\begin{array}{llll}X & X & X & X\end{array}$

- Nyanyian secara solo atau kelompok

X $\quad$ X -1

bergantian, diiringi terbangan, lirik

bahasa Indonesia atau Arab yang berupa

Shalawat;

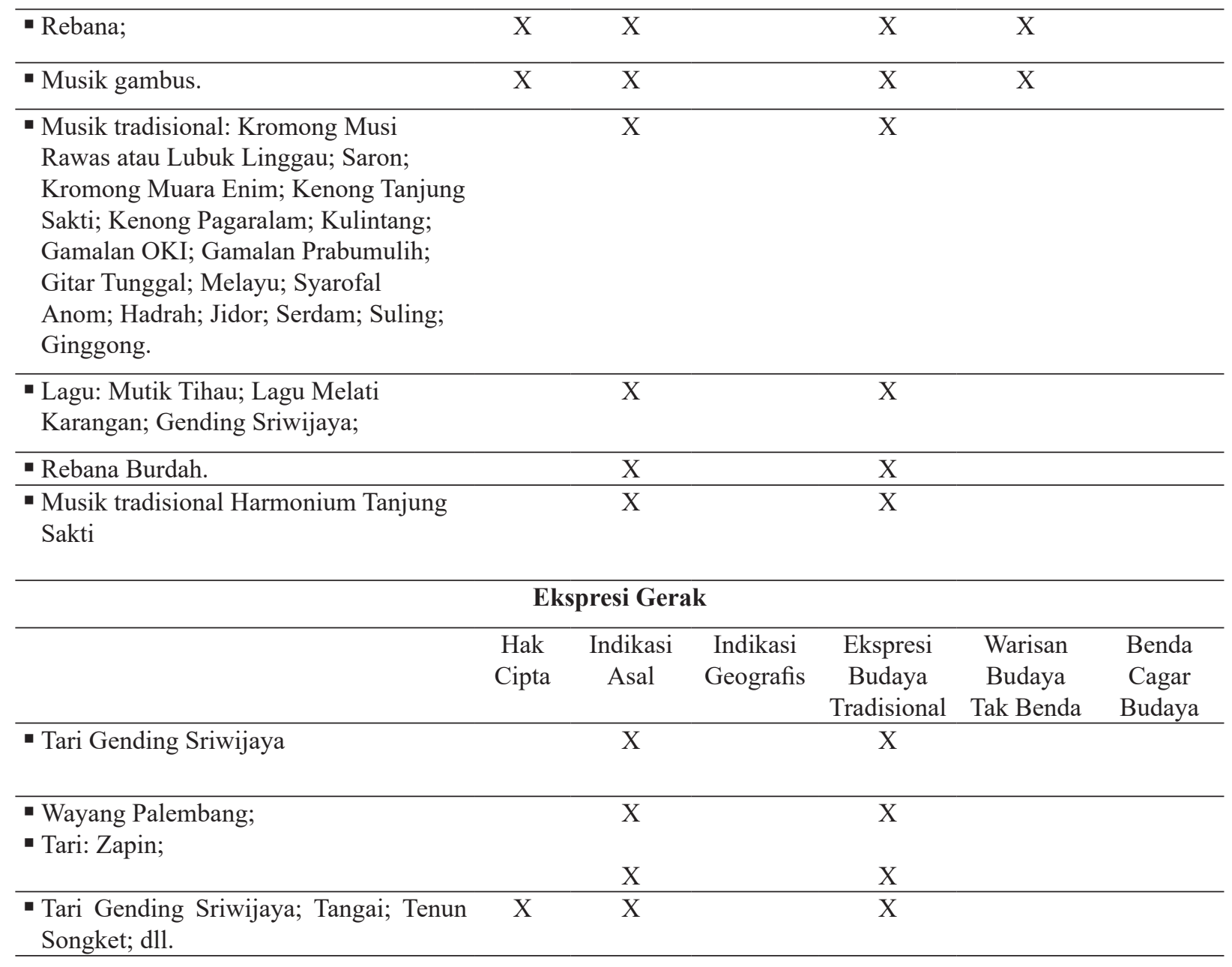




\begin{tabular}{|c|c|c|c|c|c|c|}
\hline \multicolumn{7}{|c|}{ Teater } \\
\hline & $\begin{array}{l}\text { Hak } \\
\text { Cipta }\end{array}$ & $\begin{array}{l}\text { Indikasi } \\
\text { Asal }\end{array}$ & $\begin{array}{l}\text { Indikasi } \\
\text { Geografis }\end{array}$ & $\begin{array}{l}\text { Ekspresi } \\
\text { Budaya } \\
\text { Tradisional }\end{array}$ & $\begin{array}{l}\text { Warisan } \\
\text { Budaya } \\
\text { Tak Benda }\end{array}$ & $\begin{array}{l}\text { Benda } \\
\text { Cagar } \\
\text { Budaya }\end{array}$ \\
\hline - Wayang Palembang & & $\mathrm{X}$ & & $\mathrm{X}$ & $\mathrm{X}$ & \\
\hline - Abdul Muluk dan Bangsawan & $\mathrm{X}$ & & & $\mathrm{X}$ & & \\
\hline \multicolumn{7}{|c|}{ Seni Rupa } \\
\hline & $\begin{array}{l}\text { Hak } \\
\text { Cipta }\end{array}$ & $\begin{array}{c}\text { Indikasi } \\
\text { Asal }\end{array}$ & $\begin{array}{c}\text { Indikasi } \\
\text { Geografis }\end{array}$ & $\begin{array}{l}\text { Ekspresi } \\
\text { Budaya } \\
\text { Tradisional } \\
\end{array}$ & $\begin{array}{c}\text { Warisan } \\
\text { Budaya } \\
\text { Tak Benda }\end{array}$ & $\begin{array}{l}\text { Benda } \\
\text { Cagar } \\
\text { Budaya }\end{array}$ \\
\hline $\begin{array}{l}\text { - Lukisan pada dinding gua dengan } \\
\text { bentuk hewan dalam ornamen } \\
\text { (zoomorphic); }\end{array}$ & & $\mathrm{X}$ & & $\mathrm{X}$ & & $\mathrm{X}$ \\
\hline - Arca batu gajah. & & $\mathrm{X}$ & & $\mathrm{X}$ & & $\mathrm{X}$ \\
\hline - Arca dan candi zaman Hindu-Budha & & $\mathrm{X}$ & & $\mathrm{X}$ & & $\mathrm{X}$ \\
\hline - Ukiran di atas kayu; Kaligrafi; & & $\mathrm{X}$ & & $\mathrm{X}$ & & \\
\hline $\begin{array}{l}\text { - Arsitektur Mesjid Agung Palembang; } \\
\text { Rumah Limas; }\end{array}$ & & $\mathrm{X}$ & & $\mathrm{X}$ & & $\mathrm{X}$ \\
\hline - Replika arsitektur & $\mathrm{X}$ & $\mathrm{X}$ & $\mathrm{X}$ & $\mathrm{X}$ & & \\
\hline - Makam para raja di Palembang. & & & & $\mathrm{X}$ & & $\mathrm{X}$ \\
\hline - Kerajinan songket Palembang & $\mathrm{X}$ & $\mathrm{X}$ & $\mathrm{X}$ & $\mathrm{X}$ & & \\
\hline \multicolumn{7}{|c|}{ Upacara Adat } \\
\hline & $\begin{array}{l}\text { Hak } \\
\text { Cipta }\end{array}$ & $\begin{array}{l}\text { Indikasi } \\
\text { Asal }\end{array}$ & $\begin{array}{l}\text { Indikasi } \\
\text { Geografis }\end{array}$ & $\begin{array}{l}\text { Ekspresi } \\
\text { Budaya } \\
\text { Tradisional }\end{array}$ & $\begin{array}{l}\text { Warisan } \\
\text { Budaya } \\
\text { Tak Benda }\end{array}$ & $\begin{array}{l}\text { Benda } \\
\text { Cagar } \\
\text { Budaya }\end{array}$ \\
\hline $\begin{array}{l}\text { - Rangkaian Adat Menjelang Perkawinan; } \\
\text { saat Perkawinan dan setelah Upacara } \\
\text { Perkawinan }\end{array}$ & & $\mathrm{X}$ & & $\mathrm{X}$ & & \\
\hline
\end{tabular}

Sumber: Pemerintah Provinsi Sumatera Selatan, $2006^{41}$ dan Anna Kumari, 2004. ${ }^{42}$

Pada masa kini, secara yuridis pragmatis, menjadi tidak begitu penting untuk menentukan apakah Indonesia harus memiliki undang-undang yang khusus untuk mengatur pemanfaatan Sumber Daya Budaya Tak Benda, atau bersandar pada Undang-Undang Hak Cipta dan beberapa peraturan lain yang sudah ada. Dalam konteks perlindungan Sumber Daya Budaya Tak Benda, aspek paling dominan adalah kepemilikan atau pengembanan hak yang bersifat komunal. Hal ini mensyaratkan penguatan di dua lini, pertama, lini pemberdayaan komunitas lokal yang akan secara yuridis menjadi pemegang hak komunalnya, dan kedua, lini penentuan wilayah khusus, yang bisa diistilahkan sebagai wilayah suaka budaya tak benda, yang tidak selalu sama dengan wilayah administratif suatu daerah. Perlindungan integratif kekayaan budaya, baik yang bersifat sui generis, lebih berdasarkan Undang-Undang Hak Cipta dan peraturan-peraturan positif lain yang tersebar, atau pun sistem kombinasi keduanya, selama tidak secara riil berpihak kepada kepentingan pemangku atau pengemban budaya, dan tidak menghasilkan perumusan keuntungan finansial maupun non-finansial yang adil bagi

41 Lihat pada Pemerintah Provinsi Sumatera Selatan, 2006, Direktori Kesenian Sumatera Selatan, Dinas Kebudayaan dan Pariwisata Sumatera Selatan, Palembang.

42 Lihat juga pada Anna Kumari, 2004, Tujuh Hari Tujuh Malam: Upacara Adat Perkawinan Palembang Darussalam, Kementerian Pendidikan dan Kebudayaan Direktorat Jenderal Kebudayaan, Palembang. 
mereka, akan bermakna gagal.

\section{Kesimpulan}

Kesimpulan yang dapat ditarik berdasarkan pembahasan di atas adalah sebagai berikut:

1. Kategori potensi Sumber Daya Budaya Tak Benda yang dapat dilindungi oleh Hukum KI meliputi ekspresi verbal tekstual, seperti karya sastra tradisi lisan maupun yang tertulis di situs-situs; ekspresi musik, baik vokal, instrumental maupun kombinasinya, yang banyak berkembang dari zaman berkembangnya kebudayaan Islam hingga saat ini; ekspresi gerak, antara lain tari Gending Sriwijaya yang sangat terkenal dan telah mengalami revitalisasi; ekspresi teater, seperti Wayang Palembang dan sandiwara tradisional; ekspresi seni rupa, yaitu berbagai seni rupa murni dan seni terapan yang berkembang sejak zaman pra-sejarah hingga saat ini; dan upacara adat, yang paling popular adalah upacara perkawinan adat Palembang Darussalam.

2. Sistem perlindungan integratif-maksimal dengan membuat model suaka sumber daya budaya tak benda, baik di tingkat lokal maupun nasional Indonesia, dapat dilakukan dengan cara membuat suatu sistem perlindungan komprehensif dan inklusif, artinya, dengan memanfaatkan peraturan perundangan-undangan, baik di tingkat Undang-Undang maupun Peraturan Pelaksana, termasuk juga institusi dan prosesproses terkait, tidak hanya di wilayah Hukum KI, tetapi juga Hukum Lingkungan, Hukum Pemerintahan Daerah, Hukum Media dan Teknologi Informasi.

\section{DAFTAR PUSTAKA}

\section{A. Buku}

Ayu, Miranda Risang, et al., 2013, Hukum Sumber Daya Genetik, Pengetahuan Tradisional, dan Ekspresi Budaya Tradisional di Indonesia, Alumni, Bandung.

Dinas Kebudayaan dan Pariwisata Provinsi Sumatera Selatan, 2006, Profil Peninggalan Sejarah dan Purbakala Sumatera Selatan, Dinas Kebudayaan dan Pariwisata Provinsi Sumatera Selatan, Palembang.

Erlina, "Kearifan Lingkungan pada Masyarakat Basemah, Lahat, Sumatera Selatan", dalam Purba, Jonny, 2003, Bunga Rampai Kearifan Lingkungan, Kementerian Lingkungan Hidup, Jakarta.

Halim, Amran, 2014, Direktori Kesenian Sumatera

Selatan, Dinas Kebudayaan dan Pariwisata Provinsi Sumatera Selatan, Palembang.

Kumari, Anna, 2004, Tujuh Hari Tujuh Malam: Upacara Adat Perkawinan Palembang Darussalam, Kementerian Pendidikan dan Kebudayaan Direktorat Jenderal Kebuda- yaan, Palembang.

Pemerintah Provinsi Sumatera Selatan, 2006, Direktori Kesenian Sumatera Selatan, Dinas Kebudayaan dan Pariwisata Sumatera Selatan, Palembang.

Putra, Heddy Shri Ahimsa, 2006, Strukturalisme Levi-Strauss: Mitos dan Karya Sastra, Kepel Press, Yogyakarta,

\section{B. Artikel Jurnal}

Zaini, Zulfi Diane, "Implementasi Pendekatan Yuridis Normatif dan Pendekatan Normatif Sosiologis dalam Penelitian Ilmu Hukum", Jurnal Pranata Hukum, Vol. 6 No. 2, Juli 2011.

\section{Makalah}

Situngkir, Hokky, "Kekayaan Budaya Indonesia", Makalah, Indonesian Archipelago Culture Initiatives (IACI) The National Workshop on Intellectual Property and the Documentation and Establishment of Database of Traditional Knowledge, Folklore and Intangible Cultural 
Heritage, UPT HKI UNPAD bekerja sama dengan Kementerian Luar Negeri, Kementerian Budaya dan Pariwisata, serta World Intellectual Property Organization (WIPO), 2011.

\section{Internet}

Irianto, Sulistyowati, "Praktik Penelitian Hukum:

Perspektif Sosiolegal", http://www.bphn. go.id/data/documents/materi_cle_8_prof_ $d r$ sulistyowati_irianto_full.pdf, diakses 30 Mei 2013.

Pemerintah Provinsi Sumatera Selatan, "Sejarah Sumatera Selatan", http://www.sumselprov. go.id/index.php? module $=$ content $\& i d=9$, diakses pada 30 Mei 2013.

Pemerintah Provinsi Sumatera Selatan, "Sekilas Sumatera Selatan", http://www.sumselprov. go.id/profil/sekilas, dikases tanggal 12 September 2014.

\section{E. Peraturan Perundang-Undangan}

Undang-Undang Nomor 28 Tahun 2014 tentang Hak Cipta (Lembaran Negara Republik Indonesia Tahun 2014 Nomor 266, Tambahan Lembaran Negara Republik Indonesia Nomor 5599). Undang-Undang Nomor 20 Tahun 2016 tentang Merek dan Indikasi Geografis (Lembaran
Negara Republik Indonesia Tahun 2016 Nomor 252, Tambahan Lembaran Negara Republik Indonesia Nomor 5953).

Peraturan Presiden Nomor 78 Tahun 2007 tentang pengesahan Konvensi UNESCO tentang Pelestarian Warisan Budaya Takbenda 2003 (Lembaran Negara Republik Indonesia Tahun 2007 Nomor 81).

Keputusan Presiden Nomor 19 Tahun 1997 tentang Pengesahan WIPO Copyright Treaty 1996 (Lembaran Negara Republik Indonesia Tahun 1997 Nomor 36).

Keputusan Presiden Nomor 74 Tahun 2004 tentang pengesahan WIPO Performances and Phonograms Treaty (WPPT) 1996 (Lembaran Negara Republik Indonesia Tahun 2004 Nomor 93).

\section{F. Lain-Lain}

Agreement on Trade Related Aspects of Intellectual Property Rights, Annex Ic Agreement of Establishing of the World Trade Organization, 1994.

Wawancara dengan Farida, Dosen Sejarah, Universitas Sriwijaya, 3 Oktober 2014.

Wawancara dengan Heri Wijaya Kepala Bidang Kebudayaan, Dinas Kebudayaan dan Pariwisata, Provinsi Sumatera Selatan, 2 Oktober 2014. 